\title{
PSYGHIATRIC ASPECTS OF SIR THOMAS BROWNE WITH A NEW EVALUATION OF HIS WORK
}

by

\author{
JEROME M. SGHNEGK
}

IN a recent study of Religio Medici, Browne's classic contribution, it was claimed that aside from having been described as a religious, spiritual, philosophical, and literary production, this unusual volume appeared to be, in part, a psychological work in the modern sense. ${ }^{1} \mathrm{~A}$ variety of excerpts were offered in support of this conclusion. ${ }^{2}$ These writings, scattered throughout the text, illustrated Browne's keen psychological insights and furnished examples of psychological dynamisms which in present day terms include mechanisms of compensation, rationalization, displacement, identification, introjection, repression, and reaction formation. Others are present, and Browne's observations have been incorporated into the growing body of a modern psychology of personality. The ability to view his contribution in such terms is possible only now because of recent trends in medico-psychological study. Prior to the emergence of today's theoretical concepts and investigative methods, a synthesis of his psychological observations in this way could not have been achieved. It had to await certain historical developments, particularly the unfolding of some psychoanalytic formulations and their moulding into the framework of a dynamic psychiatry.

A number of the insights revealed in Browne's Religio Medici may be found from time to time in the writings of creative and scholarly men. Some philosophers and novelists are two pertinent examples. In the case of Browne, the important point is that he was a practising physician, and his psychological intuitiveness and awareness must be viewed within the context of his basic life work. This reinforces interest in him as a figure in medical history, and specifically the history of medical psychology or psychiatry.

In keeping with these points, it has been mentioned that in his classic work Browne did not use the term 'unconscious', but his delineations of personality functioning demonstrated basic knowledge of unconscious components in human behaviour.

Three aspects of Sir Thomas Browne (1605-82) have been presented. One has to do with his views on the devil and witches, beliefs in which he shared with other scientists and intellectuals such as Francis Bacon, William Harvey, and Robert Boyle. A second demonstrates his knowledge about mental derangement transcending only a limited link with demonology, thus giving evidence of insights that would be consistent with experience and facts available 


\section{Jerome M. Schneck}

to physicians preceding him and of his time also. Finally, writings constituting part of the Religio Medici were presented to show Browne as a true forerunner of psychologically minded physicians of today. His perceptive, discerning observations reflect awareness of psychological motivations and functioning which have become further organized and enriched as part of present-day psychological medicine. On this score Browne deserves additional study and evaluation. Further pursuit of this interest has led to reexamination of some portions of Religio Medici, ${ }^{3}$ a study of Letter To A Friend, ${ }^{4}$ and an analysis of Christian Morals. ${ }^{5}$

Although Browne died in 1682, Letter To A Friend was found later among his possessions and published in 1690 . It has general medical interest in many ways which will not be elaborated here. Christian Morals was also published after his death. It may have been related to the writing of Letter To A Friend, judging by some aspects of its content. Apparently it was not a continuation of Religio Medici. The development of the latter work has already been outlined. ${ }^{6}$

Browne had some interest in dreams. He was observant but evidently not profound. There are indications of awareness of some symbolism and reflections of anxiety in dream content. In Letter To A Friend ${ }^{4}$ we find:

Some Dreams I confess may admit of easie and feminine Exposition: he who dreamed that he could not see his right Shoulder, might easily fear to lose the sight of his right Eye; he that before a Journey dreamed that his Feet were cut off, had a plain warning not to undertake his intended Journey. He rejects that for which he apparently could find no substantiation. But why to dream of Lettuce should presage some ensuing disease, why to eat figs should signify foolish Talk, why to eat Eggs great Trouble, and to dream of Blindness should be so highly commended, according to the oneirocritical Verses of Astrampsychus and Nicephorus, I shall leave unto your Divination.

We find that he recognizes the tendency in some people to see in dreams what they hope to discover. Browne also makes some simple correlations between dream content and symbolism with states of health and illness.

And therefore I could not but take notice how his Female Friends were irrationally curious so strictly to examine his Dreams, and in this low state to hope for the Fantasms of Health. He was now past the healthful Dreams, of the Sun, Moon, and Stars in their Clarity and Proper Courses. 'Twas too late to dream of Flying, of Limpid Fountains, smooth Waters, white Vestments, and fruitful green Trees, which are the Visions of healthful Sleeps, and at good distance from the Grave.

And they were also too deeply dejected that he should dream of his dead Friends, inconsequently divining, that he would not be long from them; for strange it was not that he should sometimes dream of the dead whose Thoughts run always upon Death; beside, to dream of the Dead, so they appear not in dark Habits, and take nothing away from us, in Hippocrates his Sense was of good signification: for we live by the dead, and every thing is or must be so before it becomes our Nourishment.

Then Browne in a modern fashion looks for latent significance beyond manifest content.

And Cardan, who dream'd that he discoursed with his dead Father in the Moon, made thereof no mortal Interpretation: and even to dream that we are dead, was no condemnable 


\section{Psychiatric Aspects of Sir Thomas Browne with a New Evaluation of His Work}

Fantasm in old oneirocriticism, as having a signification of Liberty, vacuity from Cares, exemption and freedom from Troubles, unknown unto the dead.

The dream dynamism here is akin to representation by the opposite in psychoanalytic constructs.

Some present interests in dream psychology involve reflections of unconscious awareness of ill health in dream content antedating objective indications or conscious awareness of such illness. Through Browne, such views can be traced to Hippocrates.

From the Thoughts of Sleep, when the Soul was conceived nearest unto Divinity, the Ancients erected an Art of Divination, wherein while they too widely expatiated in loose and inconsequent Conjectures, Hippocrates wisely considered Dreams as they presaged Alterations in the Body, and so afforded hints toward the preservation of Health, and prevention of Diseases; and therein was so serious as to advise Alteration of Diet, Exercise, Sweating, Bathing, and Vomiting; and also so religious, as to order Prayers and Supplications unto respective Deities....

More dream material is to be found in Religio Medici. ${ }^{2} \mathrm{He}$ shows his awareness of the wish-fulfilment aspects of certain dreams. In his own way he implies the delusional aspects of dream life, suggestive of comparisons today between dream mechanisms and distortions in some psychotic processes. Apparently he views dream life as reflecting a peculiar representation of waking mental functioning. He recognizes psychological activities in sleep as the unfolding of more extensive aspects of personality than are in evidence during the state of awareness in waking activity. More is seen of the self when dream states are examined. He is attuned to the fact that special aspects of personality may come into view in dreams than are evident in the waking state. There is more to sleep than meets the eye and he clearly feels it to be an issue of serious interest. $\mathrm{He}$ suspects that the richness in dream life and the potential horizons of human thought relate in some way to the mental state of people approaching death. The idea is suggestive of some literary productions of Edgar Allan Poe who showed considerable curiosity about alterations in states of consciousness. ${ }^{9}$ Let us examine these views in the words of Browne:

There is surely a neerer apprehension of any thing that delights us in our dreames, than in our awakened senses; with this I can be a King without a Crowne, rich without a royalty, in heaven though on earth, enjoy my friend and embrace him at a distance; without which I cannot behold him; without this I were unhappy; for my awaked judgment discontents me, even whispering unto me, that I am from my friend; but my friendly dreams in the night requite me, and make me thinke I am within his armes. I thanke God for my happy dreames, as I doe for my good rest; for there is a satisfaction in them unto reasonable desires, and such as can be content with a fit of happinesse; and surely it is not a melancholy conceite to thinke we are all asleepe in this world, and that the conceits of this life are as meare dreames to those of the next, as the Phantasmes of the night, to the conceits of the day. There is an equall delusion in both, and the one doth but seeme to bee the embleme and picture of the other; we are somewhat more than our selves in our sleepes, and the slumber of the body seemes to bee but the waking of the soule. It is the ligation of sense, but the liberty of reason; our waking conceptions doe not match the fancies of our sleepes. At my Nativity, my ascendant was the watery signe of Scorpius; I was born in the Planetary hour of Saturne, and I think I have a piece of that Leaden Planet in me. I am no way facetious, nor disposed for the mirth and 


\section{Ferome M. Schneck}

galliardize of company, yet in one dreame I can compose a whole comedy, behold the action, apprehend the jests, and laugh my selfe awake at the conceits thereof: were my memory as faithfull as my reason is then fruitfull, I would never study but in my dreames; and this time also would I chuse for my devotions, but our grosser memories have then so little hold of our abstracted understandings, that they forget the story, and can only relate to our awaked soules, a confused and broken tale of what hath passed. Aristotle, who hath written a singular tract of sleepe, hath not me thinkes thoroughly defined it, nor yet Galen, though hee seeme to have corrected it; for those Noctambuloes and night-walkers, though in their sleepe, doe yet enjoy the action of their senses: we must therefore say that there is something in us that is not in the jurisdiction of Morpheus; and that these abstracted and ecstaticke soules doe walke about in their owne corps, as spirits with the bodies they assume, wherein they seeme to heare, see, and feele, though indeed the organs are destitute of sense, and their natures of those faculties that should informe them. Thus it is observed that men sometimes, upon the houre of their departure, doe speake and reason above themselves; For then the soule, beginning to bee freed from the ligaments of the body, begins to reason like her selfe, and to discourse in a straine above mortality.

Returning to Letter To A Friend, 4 we find some comments on aspects of psychopathology in the senile.

In this deliberate and creeping progress unto the Grave, he was somewhat too young, and of too noble a mind, to fall upon that stupid Symptom observable in diverse Persons near their Journey's end, and which may be reckoned among the mortal Symptoms of their last Disease; that is, to become more narrow-minded, miserable and tenacious, unready to part with anything when they are ready to part with all, and afraid to want when they have no time to spend; meanwhile Physicians, who know that many are mad but in a single depraved Imagination, and one prevalent Decipiency; and that beside and out of such single Deliriums a Man may meet with sober Actions and good Sense in Bedlam; cannot but smile to see the Heirs and concerned Relations, gratulating themselves on the sober departure of their Friends; and though they behold such mad covetous Passages, content to think they dye in good Understanding, and in their sober Senses.

Aside from the issue of senile psychopathology, Browne shows awareness of the circumscribed, systematized delusions in some patients.

The matter of delusion reminds us again of the cult of demonology. Browne is frequently associated with a witch trial containing his testimony. ${ }^{7,8}$ Although he apparently did not testify against the accused, some students of Browne harbour the wish that he had been more outspoken in opposition to the trend of the times. ${ }^{6}$ Remarks in Christian Morals ${ }^{5}$ are of the type that might please those favouring a stronger stand by Browne. In any case they enhance the view of the larger man.

While thou so hotly disclaimest the Devil, be not guilty of Diabolism. Fall not into one name with that unclean Spirit, nor act his nature whom thou so much abhorrest; that is, to Accuse, Calumniate, Backbite, Whisper, Detract, or sinistrously interpret others. Degenerous depravities, and narrow-minded vices! not only below St. Paul's noble Christian but Aristotle's True Gentleman.

This theme is elaborated later in the same work. Satanic agency is accepted, but special stress is placed on the role of personalities that perpetuate malevolence.

Though the Quickness of thine Ear were able to reach the noise of the Moon, which some think it maketh in it's rapid revolution; though the number of thy ears should equal Argus 


\section{Psychiatric Aspects of Sir Thomas Browne with a New Evaluation of His Work}

his Eyes; yet stop them all with the wise man's wax, and be deaf unto the suggestions of Talebearers, Calumniators, Pickthank or Malevolent Delators, who while quiet Men sleep, sowing the Tares of discord and division, distract the tranquility of Charity and all friendly Society. These are the Tongues that set the world on fire, cankers of reputation, and like that of Jonas his Gourd, wither a good name in a night. Evil Spirits may sit still, while these Spirits walk about and perform the business of Hell. To speak more strictly, our corrupted hearts are the Factories of the Devil, which may be at work without his presence. For when that circumventing Spirit hath drawn Malice, Envy, and all unrighteousness unto well rooted habits in his disciples, iniquity then goes on upon its own legs, and if the gate of Hell were shut up for a time, Vice would still be fertile and produce the fruits of Hell. Thus when God forsakes us, Satan also leaves us. For such offenders he looks upon as sure and sealed up, and his temptations then needless unto them.

An interesting passage in Christian Morals ${ }^{5}$ shows not only Browne's reflections on conscience, but his recognition of the unconscious aspects of super-ego functioning, in line with previously expressed views about his intuitive perceptiveness of more total psychological functioning than is usually encountered.

Paint not the sepulcher of thyself, and strive not to beautify thy corruption. Be not an Advocate for thy Vices, nor call for many Hour-Glasses to justify thy imperfections. Think not that always good which thou thinkest thou canst always make good, nor that concealed which the Sun doth not behold. That which the Sun doth not now see will be visible when the Sun is out, and the Stars are fallen from Heaven. Meanwhile there is no darkness unto Conscience, which can see without Light, and in the deepest obscurity give a clear Draught of things, which the Cloud of dissimulation hath conceal'd from all eyes. There is a natural standing Court within us, examining, acquitting, and condemning at the Tribunal of ourselves, wherein iniquities have their natural Thetas and no nocent is absolved by the verdict of himself. And therefor although our transgressions shall be tryed at the last bar, the process need not be long: for the judge of all knoweth all, and every Man will nakedly know himself. And when so few are like to plead not Guilty, the Assize must soon have an end.

Here is an indication of Browne's recognition of inner psychological conflicts and a suggestion that he fathomed tendencies to externalize such conflicts in overt behaviour. Parenthetical additions are the editorial footnotes in the text. ${ }^{5}$

Be not a Hercules furens abroad, and a Poltroon within thyself. To chase our Enemies out of the Field, and be led captive by our Vices; to beat down our Foes, and fall down to our Concupiscences; are Solecisms in Moral Schools, and no Laurel attends them. To well manage our Affections, and wild Horses of Plato, are the highest Circenses: and the noblest Digladiation (fencing match) is in the Theater of ourselves; for therein our inward Antagonists, not only like common Gladiators, with ordinary Weapons and down right Blows make at us, but also like Retiary and Laqueary (the retiarius or laquearius was a prize-fighter, who entangled his opponent in a net, which by some dextrous management he threw upon him) Combatants, with Nets, Frauds, and Entanglements fall upon us. Weapons for such combats are not to be forged at Lipara: Vulcan's Art doth nothing in this internal Militia; wherein not the armour of Achilles, but the Armature of St. Paul, gives the Glorius day, and Triumphs not Leading up into Capitals, but up into the highest Heavens. And therefore while so many think it the only valour to command and master others, study thou the Dominion of thyself, and quiet thine own Commotions. Let Right reason be thy lycurgus, and lift up thy hand unto the Law of it: move by the Intelligences of the superior Faculties, not by the Rapt of Passion, nor merely by that of Temper and Constitution. They who are merely carried on by the Wheel of such inclinations, without the Hand and Guidance of Sovereign Reason, are but the Automatous part of mankind, rather lived than living, or at least underliving themselves. 


\section{Ferome M. Schneck}

The following shows Browne's sensitivity to the subtleties of distortion, in addition to a variety of mechanisms alluded to previously.

Some Truths seem almost Falsehoods and some Falsehoods almost Truths; wherein Falsehood and Truth seem almost aequilibriously stated, and but a few grains of distinction to bear down the ballance. Some have digged deep, yet glanced by the Royal Vein, and a Man may come unto the Pericardium, but not the Heart of Truth. Besides, many things are known, as some are seen, that is by Parallaxis, or at some distance from their true and proper beings, the superficial regard of things having a different aspect from their true and central natures. And this moves sober Pens unto suspensory and timorous assertions, nor presently to obtrude them as Sybils leaves, which after considerations may find to be but folious appearances, and not the central and vital interiours of Truth.

Browne commented on certain types of relationships under the category of imitation. In his description offered now it may be noted that only the last part of his remarks tend more to fit a mechanism of imitation. The first part tends to express a combination of some elements of idealization and identification in accordance with current terminology for these psychological dynamisms.

He honours God who imitates him. For what we virtuously imitate we approve and Admire; and since we delight not to imitate Inferiors, we aggrandize and magnify those we imitate; since also we are most apt to imitate those we love, we testify our affection in our imitation of the Inimitable. To affect to be like may be no imitation. To act, and not to be what we pretend to imitate, is but a mimical conformation, and carrieth no Virtue in it.

The very last comment also implies his appreciation of different levels of selfawareness.

Projection and rationalization come into view when he describes some behaviour with reference to astrological leanings.

Think not to fasten thy imperfections on the Stars, and so despairingly conceive thy self under a fatality of being evil. Calculate thyself within, seek not thyself in the Moon, but in thine own Orb or Microcosmical Circumference. Let celestial aspects admonish and advertise, not conclude and determine thy ways. For since good and bad Stars moralize not our Actions, and neither excuse or commend, acquit or condemn our Good and Bad Deeds at the present or last Bar, since some are Astrologically well disposed who are morally highly vicious; not Celestial Figures, but Virtuous Schemes, must denominate and state our Actions.

We find Browne's curious manner of describing lag in psychological maturation. His mode of expression and moralizing are characteristic of many parts of his writings.

Confound not the distinctions of thy Life which Nature hath divided: that is, youth, Adolescence; Manhood, and old Age, nor in these divided Periods, wherein thou art in a manner Four, conceive thyself but One. Let every division be happy in its proper Virtues, nor one Vice run through all. Let each distinction have its salutary transition, and critically deliver thee from the imperfections of the former, so ordering the whole, that Prudence and Virtue may have the largest Section. Do as a Child but when thou art a Child, and ride not on a Reed at twenty. He who hath not taken leave of the follies of his Youth, and in his maturer state scarce got out of that division, disproportionately divideth his Days, crowds up the latter part of his Life, and leaves too narrow a corner for the Age of Wisdom, and so hath room to be a Man scarce longer than he hath been a Youth. Rather than to make this confusion, anticipate the Virtues 


\section{Psychiatric Aspects of Sir Thomas Browne with a New Evaluation of His Work}

of Age, and live long without the infirmities of it. So mayst thou count up thy days as some do Adams (Adam thought to be created in the State of Man about thirty years Old), that is, by anticipation, so mayst thou be coetaneous unto thy Elders, and a Father unto thy contemporaries.

Elsewhere in Christian Morals, ${ }^{5}$ Browne shows clear understanding of the limited perceptions we have of ourselves. What he refers to as conscience possesses the earmarks of what would be referred to now technically as the unconscious elements in superego functioning, in contrast to conscious admonishments related to the concept of the ego-ideal.

Behold thyself by inward Opticks and the Crystalline of thy Soul. Strange it is, that in the most perfect sense there should be so many fallacies, that we are fain to make a doctrine, and often to see by Art. But the greatest imperfection is in our inward sight, that is, to be Ghosts unto our own Eyes, and while we are so sharp-sighted as to look through others, to be invisible unto ourselves; for the inward Eyes are more fallacious than the outward. The Vices we scoff at in others laugh at us within ourselves. Avarice, Pride, Falsehood lye undiscerned and blindly in us, even to the Age of blindness: and, therefore, to see ourselves interiourly, we are fain to borrow other Mens Eyes; wherein true Friends are good Informers, and Censurers no bad Friends. Conscience only, that can see without Light, sits in the Areopagy and dark Tribunal of our Hearts, surveying our Thoughts and condemning their obliquities. Happy is that state of vision that can see without Light, though all should look as before the Creation, when there was not an Eye to see, or Light to actuate a Vision: wherein notwithstanding obscurity is only imaginable respectively unto Eyes. ...

\section{We also find pithy declarations such as these:}

To ruminate upon evils, to make critical notes upon injuries, and to be too acute in their apprehensions, is to add unto our own Tortures, to feather the Arrows of our Enemies, to lash our selves with the Scorpions of our Foes, and to resolve to sleep no more. As charity covers, so Modesty preventeth a multitude of sins. . . . He who discommendeth others obliquely commendeth himself. He who whispers their infirmities proclaims his own Exemptions from them. ... Open ostentation and loud vain-glory is more tolerable than this obliquity, as but containing some Froath, no ink, as but consisting of a personal piece of folly, nor complicated with uncharitableness. Superfluously we seek a precarious applause abroad: every good Man hath his plaudite within himself; and though his Tongue be silent, is not without loud Cymbals in his Breast. Conscience will become his Panegyrist, and never forget to crown and extol him unto himself.

In the practice of psychiatry today, much stress is placed on the importance of the individual as well as the group, the development of potential, and the perception and constructive expression of one's individuality. It is of interest to read Browne's views in this connexion.

Persons lightly dipt, not grain'd in generous Honesty, are but pale in Goodness, and faint hued in Integrity. But be thou what thou vertuously art, and let not the Ocean wash away thy Tincture. Stand magnetically upon that Axis, when prudent simplicity hath fixt there; and let no attraction invert the Poles of thy Honesty. That Vice may be uneasy and even monstrous unto thee, let iterated good Acts and long-confirmed habits make Virtue almost natural, or a second nature in thee. Since virtuous superstructions have commonly generous foundations, dive into thy inclinations, and early discover what nature bids thee to be, or tells thee thou may'st be. They who thus timely descend into themselves, and cultivate the good seeds which 


\section{Ferome M. Schneck}

nature hath set in them, prove not shrubs but Cedars in their generation. And to be in the form of the best of the Bad or the worst of the Good, will be no satisfaction unto them.

Finally we find:

Though the World be Histrionical, and most Men live Ironically, yet be thou what thou singly art, and personate only thy self. Swim smoothly in the stream of thy Nature, and live but one Man. To single Hearts doubling is discruciating: such tempers must sweat to dissemble, and prove but hypocritical Hypocrites. Simulation must be short: Men do not easily continue a counterfeiting Life, or dissemble unto Death. He who counterfeiteth, acts a part, and is as it were out of himself: which, if long, proves so ircksome, that Men are glad to pull off their Vizards, and resume themselves again; no practice being able to naturalize such unnaturals, or make a Man rest content not to be himself.

It should be helpful to summarize the main points of this new view of Sir Thomas Browne based on an evaluation of the psychiatric aspects of some of his writings. Apart from whatever else the Religio Medici may be, it serves in part as a psychological work with observations that sound a very modern note. The elements in this work that help to characterize it in this way find illustration also in additional writings of which Letter To A Friend and especially Christian Morals serve as examples. The sections that have been presented reflect astute psychological perceptiveness in Sir Thomas Browne and show his keen insights into human thought, feeling, and behaviour. Browne was appreciative of a number of psychological dynamisms which may be translated into modern terms under the categories of compensation, rationalization, displacement, identification, introjection, repression, reaction formation, symbolization, representation by the opposite and projection. He was interested in the ingredients of imitation and idealization. Although Browne did not use the term 'unconscious' in the modern sense in these writings, he possessed considerable knowledge about such unconscious aspects of personality functioning. His awareness of mental disease transcended the current demonological concepts of his time. He was appreciative of the use of symbols in dreams and he viewed various aspects of dreams as reflections of hidden anxieties. He attempted to correlate symbolism in dreams and general dream content with states of health and disease. He searched for latent significance behind the manifest content of dream material. He was curious about possible indications in dreams of unconscious awareness by the dreamer of conditions of ill health. Various aspects of the wish-fulfilment function in some dreams aroused his interest. Psychological activity in sleep was not dismissed as of no consequence. $\mathrm{He}$ perceived such mental activity as an extension of the mental processes witnessed in waking functions and viewed this activity as an additional indication of personality potential beyond the usual daily expressions of such potential. Browne was aware of psychopathology in senility. He was observant of circumscribed systems of delusions in some people. Although he has been linked historically in a negative way with a trial for witchcraft and believed in the devil and witches as did contemporary intellectuals, Browne shows concrete awareness of psychopathology in those who levelled troublesome and malevolent accusations at the accused because of their own distorted personalities. Browne 


\section{Psychiatric Aspects of Sir Thomas Browne with a New Evaluation of His Work}

had excellent insights into super-ego operations, was quite sensitive to the power and subtleties of inner emotional conflicts, and recognized processes of externalization of such conflict. He discerned clearly the mechanism of distortion in dreams and in general mental operations. He was keenly cognizant of varying levels of self-awareness in psychological activity. Browne viewed objectively the evidences of lag in psychological maturation. He seemed especially appreciative of an attitude predominant in present day psychiatry regarding the importance of perceiving one's own individuality and fostering its most constructive expression.

Whereas Browne's illustrious contemporary, Thomas Willis ( $162 \mathrm{I}-75)$, despite his contributions and established place in psychiatric history has been seen to have approached it as a psychiatry without psychology, ${ }^{10}$ this cannot be said of Sir Thomas Browne. This is obvious in his writings which only now would seem to be open to reevaluation as a result of their closeness to the developing themes in present day dynamic psychiatry. Such reevaluation is indeed possible only as a result of recent acquisitions in clinical experience and blossoming of helpful theoretical concepts during the past few decades.11 In comparing Browne with outstanding men of his time, it has been said that the antiquarian and mystic elements of his thinking bear emphasis, and that his interests and methods of thought were more medieval than modern. As a result, he was surpassed by his contemporaries. ${ }^{12}$ Without intending at all to minimize the evidences in support of such views, the evaluation of Browne presented now serves to point out that there is more to the man than has been appreciated as yet. In contrast to the medieval aura referred to previously, the remarkably modern note must assume its rightful place. As indicated, up until now this new view has not been possible. It has had to await the development of present day medico-psychological principles. When Browne is assessed within the context of these modern principles, the strength and richness of his thoughts and the appreciation of him as a psychologically minded physician of the seventeenth century come to more fruitful expression. It may be reasonable to predict that more elements of interest in Sir Thomas Browne will be discovered in the future. He will find a more significant place in the history of psychiatric thought. His importance in the history of medicine will be more fully perceived.

\section{REFERENCES AND NOTES}

I. Schneck, J. M. 'Sir Thomas Browne, Religio Medici, and the History of Psychiatry'. Amer. F. Psychiat., 1958, cxiv: 657-60.

2. Denon ain, J. J. Sir Thomas Browne, Religio Medici, London, Cambridge University Press, 1953. (This is a critical edition published with a bibliographical introduction and notes.) See also Denonain, J. J.: Sir Thomas Browne, Religio Medici. London, Cambridge University Press, 1955. (This contains a biographical and critical introduction.)

3. Ibid.

4. Browne, T. Letter to a Friend Upon Occasion of the Death of his Intimate Friend. In, The Religio Medici and Other Writings of Sir Thomas Browne. New York, E. P. Dutton, no date (Everyman's Library, edited by Ernest Rhys, with an introduction by C. H. Herford). 


\section{Ferome M. Schneck}

5. Browne, T. 'Christian Morals'. Ibid.

6. Finch, J. S. Sir Thomas Browne. New York, Henry Schuman, 1950.

7. Osce R, W. Selected Writings of Sir William Osler. London, Oxford University Press, 1951.

8. MAjOR, R. H. A History of Medicine (2 vols.). Springfield, Ill., Charles G. Thomas, 1954.

9. Schne Cx, J. M. 'A Medical Hypnotherapeutic Addendum to the Case of M. Valdemar', Bull. Med. Lib. Assn., 1953, xu: 144-7. See also Schneck, J. M. 'James Esdaile, Hypnotic Dreams, and Hypnoanalysis'. 7. Hist. Med. \& Allied Sci., 1951, vi, 491-5.

10. Zilboorg, G., and Henry, G. W. A History of Medical Psychology. New York, W. W. Norton, 194I.

11. For a modern psychiatric reevaluation of Browne's contemporary, Thomas Sydenham, see Schneck, J. M. 'Thomas Sydenham and Psychological Medicine', Amer. $\mathcal{F}$. Psychiat., 1957, cxin, 1034-36.

12. WAgley, M. F., and WAgley, P. F. 'Comments on Samuel Johnson's Biography of Sir Thomas Browne', Bull. Hist. Med., 1957, xxxI, 318-26. 